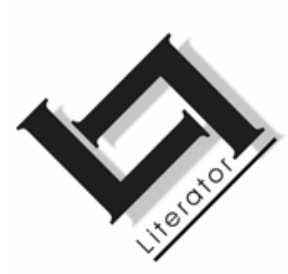

\title{
Subverting the pastoral: the transcendence of space and place in J.M. Coetzee's Disgrace
}

\author{
Susan Smit-Marais \& Marita Wenzel \\ School of Languages: English \\ Potchefstroom campus \\ North-West University \\ POTCHEFSTROOM \\ E-mail: Susan.SmitMarais@nwu.ac.za \\ Marita.Wenzel@nwu.ac.za
}

\begin{abstract}
Subverting the pastoral: the transcendence of space and place in J.M. Coetzee's Disgrace
\end{abstract}

This article investigates how J.M. Coetzee's "Disgrace" (1999) portrayed as a postcolonial and postmodern fictional event embodies, problematises and subverts the vision of the pastoral farm novel tradition by transcending traditional configurations of space and place. The novel offers a rather bleak apocalyptic vision of gender roles, racial relationships and family relations in post-apartheid South Africa and expresses the socio-political tensions pertaining to the South African landscape in terms of personal relationships. As a fictional reworking of the farm novel, "Disgrace" draws on the tradition's anxieties about the rights of (white) ownership, but within a post-apartheid context. As such, "Disgrace" challenges the pastoral farm novel's "dream topography" (Coetzee, 1988:6) of the family farm ruled by the patriarch - a topography inscribed - with the help of the invisible labour of black hands - as a legacy of power and ownership to be inherited and cultivated in perpetuity. Accordingly, the concept "farm" is portrayed as a contested and liminal space inscribed with a history of violence and dispossession - a dystopia. This article therefore conceptualises "Disgrace" as an antipastoral farm novel that reconfigures the concept "farm" - within the context of the South African reality - by subverting, inverting and parodying the structures of space and place postulated by the pastoral farm novel. 


\section{Opsomming}

Die ondermyning van die pastorale tradisie: die transendering van ruimte en plek in J.M. Coetzee se Disgrace

Hierdie artikel ondersoek die wyse waarop "Disgrace" (1999) van J.M. Coetzee - as uitbeelding van 'n postkoloniale en postmoderne fiksionele gebeurtenis - die visie van die pastorale plaasromantradisie vergestalt, problematiseer en ondermyn deur die tradisionele konfigurasies van ruimte en plek te transendeer. Die roman bied 'n taamlike pessimistiese apokaliptiese visie van geslagsrolle, rasseverhoudings asook gesinsbande in postapartheid-Suid-Afrika en vergestalt die sosio-politiese spanning wat kenmerkend is van die SuidAfrikaanse toneel in terme van persoonlike verhoudings. "Disgrace" herskryf die plaasromantradisie en put uit dié tradisie se angs oor die regmatigheid van (wit) eienaarskap - maar binne die konteks van postapartheid. "Disgrace" betwis dus die pastorale plaasroman se "droomtopografie" van die familieplaas wat regeer word deur die patriarg - 'n droomtopografie wat gehandhaaf word met behulp van die arbeid van onsigbare swart hande en 'n nalatenskap van mag en eienaarskap wat tot in lengte van dae sal duur (Coetzee, 1988:6). As sodanig word die konsep "plaas" uitgebeeld as 'n teenstrydige ruimte wat onderskryf word deur'n geskiedenis van geweld en onteiening - 'n distopia. Hierdie artikel konseptualiseer "Disgrace" dus as 'n antipastorale plaasroman wat die konsep "plaas" - binne die konteks van die Suid-Afrikaanse werklikheid - deur die strukture van ruimte en plek wat die pastorale plaasroman herkonfigureer, te ondermyn, om te keer en te parodieer.

\section{Contextualisation}

J.M. Coetzee's novel Disgrace, deemed controversial by critics and readers alike, confronts the reader with the stark realities of the South African context - with regard to its history, socio-political complexities and ironies - and comments strongly on the failure of human sympathy as a consequence of colonialism and apartheid. The plot is focalised through the consciousness of the authorial narrator and protagonist David Lurie, a professor of modern languages who has an illicit affair with one of his students, Melanie Isaacs. This relationship leads to his dismissal and subsequent decision to take "refuge" at his daughter Lucy's smallholding ${ }^{1}$ in the

1 Even though the novel defines Lucy's land as a "smallholding", for the sake of my argument I will refer to it as a "farm", as the difference between these two concepts are relative (a smallholding constitutes a smaller area of land than a 
Eastern Cape where they are attacked and Lucy brutally raped. Thematically, the novel is largely centred on Lucy's enigmatic response to her ordeal and fate and David's (and possibly the reader's) astonishment at the choices Lucy makes. The novel offers a rather bleak apocalyptic vision of gender roles, racial relationships and family relations in post-apartheid South Africa; it expresses the socio-political tensions pertaining to the South African landscape in terms of personal relationships. Therefore, even though the events that are portrayed appear to be realistic, the verisimilitude of their representation is not the purpose of their portrayal.

As a fictional reworking of the traditional farm novel (plaasroman), Disgrace draws on the tradition's anxieties about the rights of (white) ownership, but within a post-apartheid context. Marais (2001:33) asserts that even though the novel's representation of Lucy's violation and her subsequent reaction does interrogate racerelations in South Africa, the manner in which Coetzee poses these questions "warns against answers that fall within those simplistic dualisms (Europe : Africa, coloniser : colonised and white : black) that shaped the apartheid era and which persist in the postapartheid period". Disgrace therefore destabilises the dualisms that informed the ideology of the pastoral farm novel. According to Cornwell (2002:314), Coetzee's focusing on the characters' response rather than on the attack itself, seems to be dramatising just how radical a transformation South Africans may be required to undergo, both individually and as a society, in order to recover a sense of the "grace" that has been absent in South African reality for such a long time.

Van Coller (2003:55) discerns an intertextual relation (whether it be intentional or not) between the pastoral farm novel and the postmodern/postcolonial farm novel, as the latter echoes certain common traits of the former in its presentation of typical motifs situations, character and ideas. Essentially conservative and retrospective in its approach, the pastoral farm novel or plaasroman 'thematised the nexus of the 'boer' [farmer] and his 'plaas' [farm] as a timeless icon of national and numinous identity, not only validating an unquestioned right to land but expressing also the very soul of the Afrikaner's being" (Van Wyk Smith, 2001:18). J.M. Coetzee first manifested his preoccupation with the farm novel tradition and its ideological underpinnings in In the heart of the country (1977). This

farm). Also, the part of the novel that takes place on Lucy's smallholding clearly evokes the tradition of the farm novel. 
novel deconstructs the romantic pastoral prototype of the farm novel tradition through its portrayal of a lonely and desolate farm, and through the narrator Magda, a lonely spinster suffocated by an environment of intellectual and spiritual drought. As an anti-pastoral farm novel, Disgrace elaborates on this theme and challenges the pastoral farm novel's "dream topography" (Coetzee, 1988:6) of the family farm ruled by the patriarch, inscribed - with the help of the invisible labour of black hands - as a legacy of power and ownership to be inherited and cultivated in perpetuity.

Instead, the farm is portrayed as a contested space inscribed with a history of violence and dispossession - a dystopia. Disgrace questions the validity of the pastoral, or as David Lurie calls it, "the old ländliche way of life" (p. 113) 2 in post-apartheid South Africa by exposing it as a cultural construct associated with a history of patriarchal and colonial domination. As such, Disgrace will be conceptualised as a postcolonial novel in the context of its subversion, inversion and parody of the pastoral tradition through representations of space and place, characters' interaction with context and female identity formation.

\section{Representations of space and place}

The physical location of the farm in Disgrace - the Eastern Cape border - situates the farm at the frontier of conflictual contact. As a liminal space, the border is a point for a meeting of difference and a locale of hybridity. Farred (2002:16) perceives the border as a permanent presence in J.M. Coetzee's literary landscape and configures the border as

that point on a nation's psychic and geographical map where it encounters itself in relation to others, from which it understands itself as Self and Other, where its identity is affirmed, its landscape crisscrossed and its resistance to others tested.

The Eastern Cape border has been a prominent site of historical conflict between white colonists and the indigenous black population. Since the 18th century the region has been associated with resistance against colonial invasion, strife over livestock and boundaries, and most notably, disputes over control of land. Gareth

2 Page numbers in parenthesis refer to Disgrace (Coetzee, 1999a). 
Cornwell (2003:43) points out that ironically, Salem ${ }^{3}$ - the name of the area on the Eastern Cape border where Lucy's smallholding is situated - means "peace". According to Cornwell (2002:43) the contradictory implications of this name is intensified by the fact that Salem is not an invented place but a real one. Furthermore Salem has much historical and symbolical significance as the nine Frontier Wars between the British and the Xhosa people were fought in this region in the 19th century. In Disgrace the farm's location serves to foreground the "inescapable presentness of this past" (Cornwell, 2003:44), thereby positioning it as a threatening and potentially dangerous liminal space where the "self" encounters the "other", thereby establishing a state of transition, submission and potentially, also transformation.

Petrus cautions David that the farm can simultaneously be "dangerous" (p. 64) but also not dangerous: "Everything is dangerous today. But here it is still all right, I think"' (p. 64). According to Azoulay (2002:38), this movement between time and place emphasises the historical moment at which the balance of power relations shifts in relation to place. The danger posed by the farm depends on the specific circumstances and hierarchies of race, gender, and authority. The farm in Disgrace is therefore a site where the issues of race, racism and race relations are not only most entrenched, but also most resistant to change. In the novel, the features of the Eastern Cape landscape become merged with the psyches of the characters. Gunnars (2004:12) perceives the landscape in terms of opposites: "alien and familiar, personal and foreign, hostile and safe", while Farred (2002:17) notes that the landscape and the main protagonist share an unwillingness to yield to change.

\subsection{Topography and structure}

As in the case of the pastoral farm novel, the topographical structuring of space in Disgrace invests the farm with meaning, which in turn exposes the attributes traditionally ascribed to the farm space as representative of colonial and patriarchal power structures.

3 Interestingly, "Salem" is also the name of the town that functions as setting for Arthur Miller's The Crucible (1968), based upon the witch trials held in Massachusetts during 1692. Cornwell (2003:44) suggests that in both instances the name probably had a religious implication and embodied the hope for God's blessing and protection in the face of dangers threatening the survival of the townsfolk. 
Disgrace can therefore be seen to "destabilise" the spatial constructs created by the pastoral farm novel.

Whereas the pastoral farm novel conceptualises the concept "farm" as an idyllic space and contrasts it with the city, the farm in Disgrace is inherently dystopic: isolated, alienating and dangerous, while the city, as the setting for David's transgression, is suggested to be morally dubious and ethically shallow - much like the main protagonist. According to Van Coller (2003:64) Disgrace parodies the pastoral farm novel: Disgrace does not portray a child leaving the farm for the freedoms of the city, but instead portrays a father leaving the city to seek refuge on his daughter's farm. Though initially the natural rhythms of life on the farm have a harmonising effect on David's discordant life, his life, and that of his daughter, are thrown into disorder as a result of the attack, which situates the farm as a site of chaos and turmoil.

In the novel, the term "country ways" changes its meaning almost every time it is repeated. Barnard (2003:205) suggests this is indicative of the "brutal new pressures" the old "country ways" are subjected to in the South African context of the novel. While pondering on the cruelty of Petrus's sheep having to spend their last days tied-up, David relates so-called "country ways" (p. 125) to "indifference" and "hardheartedness" (p. 125). He further contends: "If the country can pass judgement on the city, then the city can pass judgement on the country too" (p. 125). The time-honoured associations between the "country" and the "city" are therefore undermined, and it is no longer plausible to equate the city with progress and the country with simplicity and tradition. The farm in the novel is conceptualised by Petrus as "forward-looking" (p. 136) and is juxtaposed with the retrospective nature of the pastoral tradition.

Disgrace also satirises the feudal values traditionally ascribed to the South African pastoral, as it is Petrus, a black man, who takes over from his white mistress to become the feudal landowner. Thereby, he is in fact making Lucy "part of his establishment ... a tenant on his land" (p. 203, 204). Furthermore, in contrast to the pantheist characteristics often ascribed to the farm in the pastoral farm novel, Disgrace confronts the reader with a starkly realistic portrayal of the South African situation. The farm in Disgrace is therefore neither a mythical nor religious space, but rather functions as a sort of "refuge" (p. 64) from David's initial disgrace. After the rape, the farm becomes a site for existential displacement, but ultimately, also a site for the transcendence of "self" - a "transcendental" space. 
Linking up with concepts of "self", Disgrace refutes the idea of the farm being an inalienable space providing a context for determining sameness and difference. Instead, the farm in Disgrace is presented as an alien and impenetrable space - "a foreign land" (p. 197), a liminal zone representative of uncertainty and ambiguity - in which the protagonists (and the reader) are forced to renegotiate presupposed notions of "self" and "other".

Disgrace subverts the fixed and codified structure of interracial social relations associated with the pastoral farm novel by exploring social relations and interactions between white and black by means of what Barnard (2003:210) refers to as "sociolinguistic issues ... in a context of profound social transformation". It is also significant that the most difficult adjustments in perspective that the novel's white characters' have to make are expressed in terms of linguistic competence or failure. The novel's most critical moment of linguistic failure is exemplified by David's distressed thoughts when he is locked in the lavatory, powerless to help his daughter and unable to understand what their assailants are saying:

He speaks Italian, he speaks French, but Italian and French will not save him here in darkest Africa. He is helpless, an Aunt Sally, a figure from a cartoon, a missionary in cassock and topi waiting with clasped hands and upcast eyes while the savages jaw away in their own lingo preparatory to plunging him into their boiling cauldron (p. 95).

David's failure to articulate his experience in any other terms but that of the most cartoonish colonial stereotypes, links up with what J.M. Coetzee (1988:9) refers to as "the failure of the listening imagination to intuit the true language of Africa ... an inability to conceive a society in South Africa in which there is a place for the self". This failure suggests that it is only by stepping "outside" the self - a self that has been constructed by the paradigms of the colonial past that one can intuit an alternative identity more suitable to the South African context.

The pastoral farm novel conceptualises the farm as a patriarchal space, ruled over by a dominant patriarchal figure, but Disgrace challenges these traditional patriarchal terms. The (white) male protagonist, David, though extensively implicated in the structures of modern patriarchy, fails in the role of patriarchal "master". At the beginning of the novel he feels inferior and "out of place" (p. 4) in his profession while on the farm, both his daughter and Petrus resist his authority. Instead, David becomes the "right-hand man to a woman 
who specializes in sterilisation and euthanasia" (p. 91), while it is the former "servant" Petrus who becomes the "new" patriarch. Petrus' name possibly also alludes to the Biblical name Peter, which has connotations of strength, dependability and progressiveness. However, despite the novel's subversion of patriarchal hegemony, as a female character, Lucy is forced to submit to the patriarchal terms instituted by Petrus.

\subsection{Spatial orientation: conceptual coordinates and the farm novel tradition}

Viljoen (2004:113-115) identifies, among other things, nature, the traditional family nucleus, labour and the representation of the "other" as prominent conceptual coordinates in the pastoral farm novel or plaasroman and relates them to the construction of space and identity by which the farm is attributed with meaning and cultural significance. In the case of the anti-pastoral farm novel, these conceptual coordinates can also have a deconstructive function. As such, the coordinates in Disgrace destabilise and subvert the farm as source of absolute meaning.

\section{- Nature and psychological landscape}

Nature is a prominent thematic element in the pastoral farm novel tradition and is usually associated with pureness, growth and life; but sometimes also with decline, destruction and death. The South African pastoral farm novel often establishes a psychical link between the farm's white inhabitants and nature, as descriptions of nature usually foreground themes dealing with the symbiotic relationship between man and nature, and parallels it to the relationship between farmer and farm. Thereby, nature is inscribed as part of the meaning of the farm. In Disgrace, descriptions of nature and the region are used to foreground the barrenness and bleakness of the landscape. These descriptions can be seen to suggest the psychological landscape that permeates the novel. The physical landscape, described by David as "Poor land, poor soil ... Exhausted" (p. 64) can also be seen as bearing the inscriptions of South Africa's history of colonial exploitation and dispossession.

\section{- Animals as thematical elements}

Another coordinate that exists in relationship with nature is that of animals. Animals, specifically dogs, are multivalent thematical elements in Coetzee's writing. His use of dogs poses ontological questions about the overlap between human and animal, while dismantling conventional dualisms of human/animal, and life/death. 
In Coetzee's The Lives of Animals (1999b) the narrator argues against the killing and mistreatment of animals for human purposes, comparing animal existential awareness to human knowledge of death: "The knowledge we have is not abstract ... but embodied" (Coetzee, 1999a:32). The narrator furthermore suggests that this idea of "embodiedness" (p. 32) is exactly that which connects our living existence as humans to that of animals: "To be alive is to be a living soul. An animal - and we are all animals - is an embodied soul ..." (p. 33). Besides functioning as vehicles for David's character development (which will be considered in more detail further on in this article), the dog-figure in Disgrace is strongly associated with bodily suffering, the threat of shame, the prospect of redemption and the passage to and from death.

In South Africa, attitudes toward dogs have a racialised colonial history. During apartheid, so-called "white-owned" dogs as well as police dogs were attributed the social function of guarding and protecting not only white property and boundaries, but on a metaphorical level, also the apartheid system. In Disgrace, the seemingly senseless killing of the dogs by the attackers therefore has symbolic significance "in a country where dogs are bred to snarl at the mere smell of a black man" (p. 110), and can be said to constitute "revenge" (p. 110). Analogous to conventional social attitudes, the pastoral farm novel often rendered dogs and other animals as property; as beings in service of human purposes. Disgrace examines many ethical issues in connection with the way humans treat animals, such as animal-slaughter, vegetarianism, and the practice of euthanasia. The dogs in Disgrace are mostly unwanted and unloved; Woodward (2001:104) suggests that in lacking intentionality and creativity, these dogs tend to be "ciphers", embodying issues rather than functioning as subjects. As such, the dog-figure in Disgrace is representative of disruptive presences that challenge accepted ethical beliefs that exist within society: Disgrace seems to suggest that when animals merely serve a society's purposes, that society might struggle to improve the immediate social relations in which it finds itself. Accordingly, Coetzee represents animals as creatures that suffer human inflicted captivity, pain, or death, thereby creating an affinity between attitudes toward animal living and dying and human living and dying.

\section{- The traditional family nucleus}

Another conceptual coordinate that is integral to the preservation of the pastoral idyll is that of the traditional family nucleus. Thematically, the pastoral farm novel holds that to ensure the 
survival of the nation and its ideals, the upkeep of the family as morally functional unit reigned over by a just and God-fearing patriarch, has to be cultivated.4 However, this coordinate is undermined in Disgrace through the portrayal of a dysfunctional, disjunctive family unit, consisting of a father with dubious morals and his lesbian daughter. The loss and dissolution of family life and the break-up of the traditional familial bond are important themes in the novel. The pastoral notion of the concept "family" as a morally functional hierarchy is therefore undermined. David struggles to fulfil the role of father and views it as a "rather abstract business" (p. 63). Splendore (2003:157) suggests that Coetzee's use of the negative father figure - "the debunking of the Myth of the Father" - suggests the failure of the fantasy concerning origins and belonging propagated by the pastoral farm novel. Furthermore, whereas the portrayal of female characters in the pastoral farm novel is relatively one-dimensional, Lucy is portrayed as a complex, multi-dimensional character whose identity formation is a central theme of the novel. Lucy can also be seen as the antithesis of the pastoral female: she is very assertive, she opposes her father's interfering ways and resists traditional gender stereotypes. Whereas the pastoral female is often portrayed as a doting care-giver to her husband and children, Lucy is single and a lesbian, initially only a care-giver to dogs and ultimately, mother to an unborn child fathered by her rapist.

\section{- The portrayal of labour as element of the pastoral genre}

As the pastoral farm novel links the concept of labour to land, nature and race, the portrayal of labour is an important element of the pastoral genre. Labour is represented as an honourable and virtuous enterprise by which ownership can physically be inscribed on the land. However, in Disgrace the concept of labour is deemphasised as it is approached rather perfunctorily and never really described or integrated into the plot. Labour is also underplayed by relating it to more domestic tasks such as feeding the dogs or tending the garden. Consequently, the pastoral notion of labour and servitude as transcendental prerequisites for land ownership is undermined.

$4 \quad$ Patriarchal figures in the pastoral farm novel are not necessarily portrayed as just and righteous, but this was the ideal the pastoral tradition ascribed to. As such, the traditional pastoral farm novel also pointed out those elements that threatened the preservation of family values, such as obstinacy and greed on the part of the patriarch. 
In White writing (1988) Coetzee locates in the genre of the farm novel an anxiety about the rights of white ownership in a colonial context, an anxiety that is revealed through the portrayal of black labour. Coetzee (1988:5) further points out that the South African pastoral had to deny the colonial history of dispossession and disownment by omitting the truth about black labour, because acknowledging the black serf's toil would threaten the position of the white man as Africa's new heir and would imply that the black "other" is entitled to stake a claim to the land. Therefore, contrary to the way in which the pastoral farm novel obscures the relation between the black "other" and labour in order to deny the possibility that the black man is entitled to stake his claim to the land, Disgrace acknowledges this link, as it is only Petrus who is associated with the carrying out of labour on the farm. Petrus himself points out his contribution to the running of the farm when he says to David "I look after the dogs and I work in the garden" (p. 64), and when Petrus and David are overseeing Lucy's market stall, David admits to himself that "Petrus is in fact the one who does the work, while he sits and warms his hands" (p. 116). Furthermore, Petrus does successfully, albeit dubiously, lay claim to Lucy's land. In accordance with the farm novel tradition, the interrelationship between labour and landownership is integrated in the novel. However, this interrelationship functions subversively so that the notion of labour as a pastoral justification of white ownership is undermined.

To David, Petrus personifies the prototypical peasant-figure: "If there is such a thing as honest toil, then Petrus bears its marks ... A peasant, a paysan, a man of the country" (p. 117). According to Marais (2001:34) Disgrace reveals the place of black labour through the foregrounding of (race) relations on the farm. The novel inverts the traditional racially determined master-slave relationship, as it is David who assists Petrus in the performance of tasks, instead of the other way around: "Petrus has emptied the concrete storage dam and is cleaning it of algae. It is an unpleasant job. Nevertheless, he offers to help (p. 119). David acknowledges the "historical piquancy" (p. 77) of the situation, which is exemplified even more when Petrus requests David to help him fit a regulator. While doing so, David realises what Petrus expects of him: "Petrus needs him not for advice on pipefitting or plumbing but to hold things, to pass him tools - to be his handlanger, in fact" (p. 136).

Petrus's claims to authority and ownership gives him a voice and an identity; he is no longer just "an old-style kaffir" (p. 140) or a "good old chap" (p. 140), but a "co-proprietor" (p. 62) who uses question- 
able methods to get what he wants. Therefore, Disgrace presents the reader with a "new world" (p. 117) in which racially marked role divisions and stereotypes such as those promulgated by the pastoral farm novel, have become obsolete.

\section{- The concept farm: alternative definitions and interpretations}

The aforementioned coordinates situate the farm in Disgrace as a subversive and liminal space constitutive of new, differentiated identities. The legacy of the "pastoral" farmer and his lineage is erased and overwritten with the legacy of the formerly dispossessed, thereby establishing the farm as a site of both social transformation and upheaval. Accordingly, Disgrace resists traditional ideologically laden definitions and implications of the term "farm". Shortly after his arrival on the farm, David describes Lucy as "[a] frontier farmer of the new breed. In the old days, cattle and maize. Today, dogs and daffodils" (p. 62). Lucy also refutes the traditional definition of what a farm is and what it means to farm when she declares "'Stop calling it the farm, David. This is not a farm; it's just a piece of land where I grow things'” (p. 200). By resisting the ideologically laden implications of the term, Lucy opens up the concept of farm in the novel to new possibilities of alternative definitions and interpretations, more befitting to the post-apartheid South African context.

\section{Anti-pastoral implications in a postcolonial framework}

As a postcolonial text, Disgrace inverts the pastoral notion of the custom of inheritance, thereby undermining the transcendental link the pastoral farm novel has created between land and identity. There is no paternal farm; instead the farm belongs to Lucy while her father is only a visitor. While David is troubled by the idea of not leaving something of himself behind when he dies, his daughter Lucy leaves "clear prints" (p. 62) on the land, thereby inscribing her existence into its history. The notion of the bond of natural right that exists between the paternal farm and those who inherit it in Disgrace is applicable to the new black farmer and his lineage, which will include Lucy's hybrid child - "a child of this earth" (p. 216). Petrus resembles the traditional patriarchal figure in every way, and in the course of the novel he builds himself a new house (signifying his new status) which "cast[s] a long shadow" (p. 197). The farm is thereby re-instated as a site of paternal rule and "lineal consciousness" (Coetzee, 1988:4), but by a black man. Furthermore, Lucy has to "buy" her right to remain on the farm and "pays" in terms of her right to land, her freedom, and her dignity. She explains 
to her father: "They see me as owing something. They see themselves as debt collectors, tax collectors" (p. 158). Thereby, the conflict between natural right and historical forces is, at least on a superficial level, resolved.

Disgrace destabilises the pastoral farm novel's hierarchical structuring of space through role reversals across divides of age, gender and race that signal irreversible changes in the lives of the characters. Petrus's role changes from that of labourer or "dog-man" (p. 64) to that of "bywoner", and from there develops to that of coowner and neighbour, and ultimately to that of owner. Inversely, the main protagonist, David, falls into "a state of disgrace", experiences a decline in social and economic status and becomes a "dog-man". Role reversals in Disgrace present the reader with "mirror-like juxtapositions" (Graham, 2002:12) that create disturbing likenesses between self and others, and between self and darker self, thereby subverting colonial power structures. However, Gräbe (2001:142) notes that it is significant that the role reversals in the novel are mostly brought about by incidences of abuse that "happen[s] every day, every hour, every minute ... in every corner of the country" (p. 98). The situation is made even more complex by the fact that the narrator has himself been guilty of transgressive and unacceptable behaviour. As such, the novel resists any positive outcome the socio-political equalisation process it depicts could have had by linking it to violence and a lack of social responsibility.

Loss, fear, guilt, sacrifice and retribution are important themes in Disgrace that are manifested physically, psychologically and emotionally in the lives of the characters: Lucy is "prepared to do anything, make any sacrifice, for the sake of peace" (p. 208 - my italics - SS-M), a viewpoint which, ironically, echoes the name of the region. Also, at the end of the novel, David performs a sacrificial gesture by "giving up" the dog, thereby reaffirming his ethical responsibility. The threat of losing the land - and therefore also one's sense of self - alluded to by the pastoral farm novel, becomes a reality in Disgrace when Lucy concedes to sign the land over to Petrus and become a "tenant ... 'A bywoner" (p. 204) on land which she owned. According to Barnard (2003:221) the word bywoner has humiliating connotations that imply indebtedness and poverty.

Disgrace therefore implies that old patriarchal structures have remained intact; the roles within it have only been reassigned along racial lines. But it is the rape of Lucy - "the price [she] has to pay for staying on" (p. 158) - that is the epitomy of loss and sacrifice and the ultimate annihilation of the pastoral idyll. According to Crang 
(1998:69) the colonial mindset categorised black male sexuality and desire as deviant, uncontrolled and threatening, especially when directed at white women. Therefore, the rape of a white woman by a black man is representative of a subconscious fear that possibly informed many of the ideologies of colonialism and apartheid.

To an extent, Lucy's fate relocates the pastoral female's rite of passage in the contemporary South African context, in that subservience and sacrifice are her only options if she wishes to avoid becoming another victim of criminality. As a ritual process, Lucy's development manifests a state of liminality. During the first stage of passage, her rape signifies the final blow to her dream of reinstating the pastoral idyll in a context of a post-apartheid social consciousness. This is followed by a time in limbo, a state of destruction, devastation and disillusionment in which Lucy is forced to relinquish the life she knew before the rape. This stage is exemplified by sacrifice and submission, as Lucy has to start over "at ground level. With nothing ..." (p. 205). Finally, she is able to create a new life narrative in which she incorporates herself into the new dominant narrative of the country and as such, Lucy's transcendence is exemplified in her potential for compassion and forgiveness. Thereby, the South African farm novel is opened up to the possibility of relinquishment - not only of land, but also of former ideals, privileges and identity constructs - by which grace may be attained and once again integrated into the landscape.

In conclusion, as a postcolonial/postmodern anti-pastoral farm novel, Disgrace reconfigures the concept farm in the context of the South African reality by subverting the structures of space and place postulated by the pastoral farm novel. As part of its ideological underpinnings, the white-owned pastoral farm is laden with idealised memories of a prosperous past, while the farm in Disgrace is a historically contested space in which the reality of the consequences of colonialism and apartheid are brought to the fore. South African pastoral notions of the concept farm as an extension of cultural and national identity are thereby undermined. Representations of space and place in the novel conceptualise the pastoral ideal to be a mere "sentimental yearning" (Coetzee, 1987:200) for a "dying enterprise" (p. 121), thereby suggesting that the farm cannot possibly become a pastoral refuge in a context lacking human sympathy and ethical action. 


\section{List of references}

AZOULAY, A. 2002. An alien woman/a permitted woman: on J.M. Coetzee's Disgrace. Scrutiny2: Issues in English Studies in Southern Africa, 7(1):3341.

BARNARD, R. 2003. J.M. Coetzee's Disgrace and the South African pastoral. Contemporary Literature, 44(2):199-224.

COETZEE, J.M. 1977. In the heart of the country. New York: Penguin.

COETZEE, J.M. 1987. Jerusalem prize acceptance speech. (In Atwell, D., ed. Doubling the point. Cambridge: Harvard University Press. p. 96-99.)

COETZEE, J.M. 1988. White writing: on the culture of letters in South Africa. Johannesburg : Radix.

COETZEE, J.M. 1999a. Disgrace. London: Vintage.

COETZEE, J.M. 1999b. The lives of animals. Princeton: Princeton University Press.

CORNWELL, G. 2002. Realism, rape, and J.M. Coetzee's Disgrace. Critique: Studies in Contemporary Fiction, 43(4):307-321.

CORNWELL, G. 2003. Disgraceland: history and the humanities in Frontier country. English in Africa, 30(2):43-68.

CRANG, M. 1998. Cultural geography. London: Routledge.

FARRED, G. 2002. Back to the borderlines: thinking race disgracefully. Scrutiny2: Issues in English Studies in Southern Africa, 7(1):16-19.

GRÄBE, I. 2001. Writing as exploration and revelation: experiencing the environment, whether local or global, as envisioned by different roleplayers in J.M. Coetzee's latest novels. Journal of Literary Studies, 17(3/4):120-144.

GRAHAM, L. 2002. "Yes, I am giving him up": sacrificial responsibility and likeness with dogs in J.M. Coetzee's recent fiction. Scrutiny 2: Issues in English Studies in Southern Africa, 7(1):4-13.

GUNNARS, K. 2004. A writer's writer: two perspectives. World Literature Today, $78(1): 12$.

MARAIS, M. 2001. Very morbid phenomena: liberal funk, the "Lucy-syndrome" and Disgrace. Scrutiny 2: Issues in English Studies in Southern Africa, 6(1):32-38.

MILLER, A. 1968 [1953]. The crucible. Hammondsworth: Penguin.

SPLENDORE, P. 2003. "No more mothers and fathers": the family sub-text in J.M. Coetzee's novels. Journal of Commonwealth Literature, 38(3):149162.

VAN COLLER, H.P. 2003. Die gesprek tussen C.M. van den Heever se werk en enkele moderne S.A. romans. Literator, 24(1):49-68, April.

VAN WYK SMITH, M. 2001. From "Boereplaas" to Vlakplaas: the farm from Thomas Pringle to J.M. Coetzee. (In Van der Merwe, C.N., ed. Strangely familiar: South African narratives in town and countryside. Cape Town: Content Solutions. p. 17-35.)

VILJOEN, H. 2004. Land, space, identity: the literary construction of space in three Afrikaans farm novels. (In Viljoen, H. \& Van der Merwe, C.N., eds. Storyscapes: South African perspectives on literature, space and identity. New York: Peter Lang. p. 107-123.)

WOODWARD, W. 2001. Dog stars and dog souls: the lives of dogs in Triomf by Marlene van Niekerk and Disgrace by J.M. Coetzee. Journal of Literary Studies, 17(3/4):90-119. 


\section{Key concepts:}

"farm": new connotations

Coetzee, J.M. - Disgrace (1999)

Disgrace as anti-pastoral farm novel

farm novel tradition: ideological underpinnings

pastoral prototype

place and space: the inverting and parodying of

\section{Kernbegrippe:}

"plaas": nuwe konnotasies

Coetzee, J.M. - Disgrace (1999)

Disgrace as antipastorale plaasroman

pastorale prototipe

plaasromantradisie: ideologiese onderstutting

plek en ruimte: die omkering en parodiëring van 